\title{
1. Women and participatory constitution-making
}

\author{
Silvia Suteu
}

\subsection{INTRODUCTION}

Popular participation has become a hot topic in constitution-making. Such participation has taken a number of forms. Referendums have increasingly been resorted to as a means to obtain popular endorsement of a new constitution, of constitutional amendments, or of other decisions with constitutional implications such as independence or membership in supranational bodies such as the European Union (EU). The 2014 independence referendum in Scotland is one such instance, and the 2016 referendum on EU membership in the United Kingdom is an example of the latter. Popular consultations and broad civic education programmes during constitution-building have also come to be seen as useful tools to broaden popular knowledge of, and ultimately ownership over, the constitutional renewal process and final product. Perhaps most radically, this recourse to the people has also taken the form of direct involvement in deliberations on constitutional reform, such as via citizen assemblystyle constitutional conventions of the type set up in Iceland (2011) and Ireland (2012).

Underlying this rise of mechanisms of popular involvement in constitution-making are normative justifications for the direct participation of the people in such processes. As will be seen, exponents of what has come to be termed 'new' or 'democratic constitutionalism' argue that recourse to the people is mandated by normative commitments to legitimate constitution-making. They also invoke practical benefits deriving from popular constitution-making, such as more inclusive and sustainable constitutions. Generally missing from these accounts, however, has been an investigation into the capacity of participatory mechanisms to incorporate and respond to the views of women. While appeals to the people have been justified on the ground of their increased legitimacy, less attention has been paid to the question of who, precisely, participates when these mechanisms are set up and whether women are adequately represented and listened to. This chapter is an effort to fill this gap in the literature. It aims 
to provide initial answers to the basic question of whether and how participation in constitution-making delivers for women. The chapter proceeds by first outlining the contours of the debate surrounding popular participation in constitution-making, identifying the benefits and potential pitfalls such participation may yield. The chapter then looks at three instances of popular involvement in constitutional change: the 2014 Scottish independence referendum, the 2012-14 Irish Constitutional Convention and the 2011-14 Tunisian constitution-making experience, analysing the level and nature of women's participation in all these processes. Subsequently, the chapter evaluates the successes and failures of participatory mechanisms such as referendums, constitutional conventions and public consultations in empowering women as equal participants, and their ability to ensure gender-sensitive deliberations. The chapter also raises questions as to whether participation is to be resorted to in all cases of constitutional reform and the propensity for it to be an obstacle to, rather than a vehicle for, gender equality.

\subsection{THE PROMISE AND LIMITS OF PARTICIPATORY CONSTITUTION-MAKING}

Calls for direct popular involvement in constitution-making have invoked several benefits deriving from such participation. These benefits can be largely grouped into three broad categories: increased legitimacy of the constitution, better chances of constitutional sustainability and overall democratic renewal. The underlying assumption is that participation's gains are for all, including women. The first of these benefits links the legitimacy of the constitution at least in part to the process of its creation. The more open and inclusive the constitution-making process, so the argument goes, the more likely it is to carry with it an educational element, 'set[ting] the tone for ordinary politics, including the peaceful transfer of power in accordance with constitutional rules' (Saunders 2012: 3). Not only can the process serve as a model for future political interactions, but it can also inspire public ownership and increased vigilance over the new constitution: the people who have participated in creating their constitution will also know when the latter has been transgressed and will demand accountability (Widner 2008: 1519). An overarching consideration here is the link between such increased procedural legitimacy of constitution-making and self-government. Participatory constitution-making thus becomes the means through which to give 
weight to 'the idea of self-governance and a perception of constitutionalism which understands civic participation as a necessity in order for a constitution to become a vibrant reflection of a political community's political imagery and self-understanding' (Bergsson and Blokker 2014: 159-60).

A second benefit links the level of inclusiveness of the constitutionmaking process to the sustainability over time of the constitution. Empirical studies have claimed that inclusion - understood as the breadth of participation in both formulating and subsequently enforcing constitutional agreements - is one of the key factors ensuring constitutional longevity (Elkins et al. 2009: 78). These studies have explained that the common knowledge created when the constitution is publicly formulated and debated leads to attachment to the constitutional project, which in turn results in self-enforcement and constitutional survival. Critics of these studies have pointed to numerous instances where elite-produced constitutional documents have been the ones to endure and, conversely, where highly participatory processes failed. Nevertheless, while not a sufficient condition, participation may have emerged as a necessary condition for constitutional sustainability, especially when combined with a normative impetus for it.

Finally, participation's benefits have been invoked as part of a broader search for alternatives to the staleness and failures of representative democracy. This search has resulted in experimentation with various participatory mechanisms meant to inject popular legitimacy into processes of decision-making and consultation, as well as revitalize popular engagement with the business of government more generally. As some scholars have noted, '[a]lthough electoral participation is generally declining, participation is expanding into new forms of action', with citizens seeking a more active role and 'prepared to challenge (and thereby engage with) existing systems and norms' (Farrell et al. 2013: 100).

At the same time as these benefits have been put forward by proponents, however, sceptics have cautioned about potential pitfalls of popular involvement in constitution-making. In post-conflict situations, for instance, the representativeness and transparency of the constitutionmaking body has been said to be less significant, given the different dynamics of the process and the premium on compromise (Widner 2008: 1533-34). There are also contexts where unilateral exercises of power can divert the constitutional process, which makes idealizing participatory constitution-making a mistake (Landau 2013). 
Most significant, however, are concerns over the potential correlation between participatory constitution-making and certain substantive decisions. Optimists expect participation to yield positive results in terms of constitutional content, such as more instruments of direct democracy, to ensure that openness and responsiveness are preserved in future lawmaking, but there are also more constraints on government authority (Carey 2009: 159-60). Pessimists distrust the capacity of participation, at least in certain forms such as the referendum, to produce positive substantive results. On the contrary, as recent examples have shown, majoritarian voting in some participatory decision-making exercises has led to the curtailment of minority rights. ${ }^{1}$

How does all this impact on women? In terms of the benefits of their participation, the optimistic expectation is that women participating equally in constitution-making should result in more legitimate constitutions which will set the tone for future political interactions. This participation should also empower women to pursue their own interests, in their own words and with their self-chosen tools, in their country's constitution. The following analysis sets out to test some of these assumptions as they have played out in recent cases of participatory constitution-building. In this way, this chapter interrogates not only whether these experiments with participation have delivered gains for women, but also whether they deliver on the promise of democratic constitutionalism understood as 'a constitutionalism always open to questioning, to dialogue, and to new understandings, aspirations and demands, one that creates a culture and institutions respectful of all citizens and a politics concluded through imaginative and inclusive fora for deliberation and accountable at every step' (Dobrowolsky and Hart 2004: 19).

\subsection{RECENT EXAMPLES OF PARTICIPATORY CONSTITUTION-MAKING: SCOTLAND, IRELAND AND TUNISIA}

In recent decades, there has been a proliferation in experimentation with mechanisms for achieving constitutional change. There are now a variety of tools, both formal and informal, which countries around the world use to achieve constitutional reform. This practical interest has been matched by scholarly interest, such as in the field of political theory, where scholars have tried to incorporate democratic innovations into theories of institutional design (Smith 2009). While authors have put forward typologies of participatory constitution-making instruments (Arato 1995, 
2012), distinguishing between forms as disparate as constituent assemblies, round tables, constitutional conventions or peace negotiations, only constitutional referendums, constituent assemblies with popular consultations and conventions modelled on citizen assemblies will be analysed here. These are by no means the sole innovative mechanisms of participatory decision-making, which also include citizen juries, deliberative polls and participatory budgeting. Indeed, one study listed over 100 different types of participation mechanisms (Rowe and Frewer 2005: 257).

Such mechanisms are promising advancements in constitutional theory and comparative constitutional design when it comes to giving voice to 'the people' in whose name the constitution will be written. Scholarship on mechanisms for the expression of popular will in constitution-making has too long remained uninterested in institutions other than constituent assemblies or roundtables (Arato 1995, 2012; Elster 1995, 1997). While these still hold promise for certain situations - indeed, the Tunisian process discussed below involved the creation of a constituent assembly there are advantages to enlarging our constitutional imagination.

In each of these case studies, the story of women's participation could be told in different ways. I have chosen to focus on two aspects: the extent of women's participation in the mechanisms discussed, in terms of raw numbers, and the substantive issues discussed and adopted and their impact on women. These two strands will be picked up again in section 1.4, which discusses the procedural and substantive burdens and opportunities which participation can afford women.

\subsubsection{The 2014 Scotland Independence Referendum}

The first example of the participatory trend is the rise in recourse to constitutional referendums, understood as referendums which bring to the voting public questions of constitutional significance (Tierney 2012). Visible instances of what has been called Europe entering the 'age of referendums' (Tierney 2014b) include the 2016 'Brexit' referendum on the UK's membership in the European Union, as well as Scotland's 2014 independence referendum, and the proposals for Catalonia to hold a similar referendum. These cases, with Quebec's two independence referendums as another example, put to the voting public the issue of sovereignty of a sub-national unit and its relationship to the plurinational state. As Stephen Tierney has argued, they challenge contemporary assumptions about the waning of nationalism (whether at the state or sub-state levels) and about the unitary character of constituent power, understood as the embodiment of a unified demos (Tierney 2008: 
229-30). Because of the importance of the choice put to a vote, achieving significant levels of popular participation, including among women, was important in all these cases. Without it, the legitimacy of decisions taken in the name of the demos would have been open to serious question.

The Scottish process was formally set in motion with the Edinburgh Agreement of 2012, which formalized the settlement reached by the UK and the Scottish Governments regarding the terms of a referendum on the independence of Scotland. The two years leading up to the referendum saw an unprecedented popular mobilization in debates on the benefits and drawbacks of independence. On the day of the referendum, voter turnout reached 84 per cent, the highest turnout at a nationwide referendum or parliamentary election in Scotland. It was also a figure in stark contrast to other UK referendums (for example, the 2011 national referendum on changing the voting system had only yielded a 42 per cent turnout, and the 2011 referendum on Welsh devolution an even more meagre 36 per cent). Significantly, popular engagement with the Scottish referendum took more diverse forms than solely turnout on the day of the vote. Voters sought out information on the question beforehand and debated it in public and private spaces, in traditional and social media, increasingly leaving political elites on the sidelines having to accept that the fate of major constitutional change was entirely in the hands of the Scottish people (Tierney 2014a). To what extent this was also true for women voters, at different stages in the referendum process, will be discussed shortly.

While independence was rejected by a margin of over 10 per cent, it became clear during the campaign that the referendum question 'Should Scotland be an independent country?' - did not reflect the full range of options the Scottish electorate wished to choose from. As would be evidenced by the process of further devolving powers to Scotland set in motion after the referendum, a No vote had come to be as much a vote for more powers to the devolved unit as a vote against independence (Cairney 2015). In many ways, then, the 2014 independence referendum was only one, albeit important, step in the ongoing process of reforming the UK constitution.

In Scotland, the initial stages of the referendum campaign were seen as triggering less interest among female voters. This phenomenon was alternatively attributed to the low levels of female participation in politics, to a more hesitant attitude or to higher levels of risk aversion among women; less stereotypical interpretations attributed women's reluctance to enter referendum debates to 'a rational response to the legalistic and narrow process and the lack of authoritative information and analysis available as to the consequences of constitutional change' 
(Bell and MacKay 2013), as well as to an absence of women's issues on the agenda due to antagonistic politics and rigid party discipline (Kenny 2014: 325). Polls consistently showed women to be more sceptical of independence, a pattern that was confirmed on voting day. Also according to polls, nothing seemed to influence the vote more than perceptions of the economic consequences of leaving the UK, with women (as well as older people, those in more affluent circumstances and those who were born elsewhere in the UK) more pessimistic about the economic consequences of independence (Curtice 2014).

Two issues are worth highlighting: the relative absence of cross-party mobilization around gender equality and the different strategies used by the opposing campaigns during the run-up to the Scottish referendum. As regards the former, the lack of a broad women's alliance was largely due to political divisions and party discipline. The groups Women for Independence, a non-aligned pro-independence group, and Women Together, a group affiliated with the No campaign, had agendas that were distinctly tied to their opposing stances on independence, with the former especially effective at mobilizing grassroots support for independence. Women for Independence (full name: 'Women for Independence - Independence for Women') has since continued to actively promote both gender equality and women's representation in Scottish politics and Scottish independence, as well as further constitutional change.

This polarized landscape contrasted with the 1997 devolution referendum on establishing a Scottish Parliament, when women's cross-party mobilization and a gender equality agenda seemed far more central to the referendum process. During that process, women had organized themselves both in party-tied groups such as the Woman's Claim of Right Group and the Scottish Labour Women's Caucus and in cross-party groups such as Engender and the Women's Coordination Group; the umbrella organization, the Scottish Convention of Women, was also set up, while a Women's Issues Group had already been established in the Scottish Constitutional Convention in 1989 (Dobrowolsky 2003: 129-30). Significantly, women then came together and rallied under the $50 / 50$ banner to lobby for 'new political institutions, new principles, new provision and new practices that were more responsive to women's concerns, more likely to tackle structural discrimination and in which women could play a more equal role. The goal was the creation of a fairer and better Scotland for women, men and children' (Bell and MacKay 2013, citing Brown 2001). Reflecting on the state of the independence debate in early 2013, Alice Brown, a member of the Consultative Steering Group for the Scottish Parliament and founding member of the Scottish Women's Coordination Group, found it divided 
and 'quite toxic in some regards', without 'that same focus on equal representation' and thus not enabling the type of broad alliance-making which had been possible in the 1990s (quoted in Murtagh 2013).

With regard to campaign strategies, the Yes and No camps appealed to female voters in different ways. The Scottish Government's White Paper outlining the benefits of independence emphasized: women's equal participation in the workforce; their equal representation on company boards; the disproportionate impact on women of Westminster policies such as tax allowances for some married couples, caps on social benefits and pension plans; as well as plans for 'transformational change to childcare in Scotland' (The Scottish Government 2013: 106, 121, 134, 151, 192-94). The latter would be achieved via 'extensive provision of early learning and childcare for all families' (The Scottish Government 2013: 192), which would in turn boost tax revenues and bring Scotland in line with female workplace participation rates found in countries such as Sweden (Klimes 2013). The promised scrapping of Trident, the nuclear programme that operated from a naval base on the west coast of Scotland, was also to free up funds for such social policies. ${ }^{2}$ ThenDeputy First Minister Nicola Sturgeon was the most prominent proindependence female voice in the debate, making frequent references to the importance of the female vote in deciding the outcome of the referendum and referring to women voters as 'naturally more sceptical', 'risk aware' (as opposed to 'risk averse') and more concerned with the practical implications of independence for them, their families and their communities, and "less likely to be moved by the "big picture" notions of statehood, flags and embassies and all that' (quoted in Newman 2014). These types of arguments were part of a broader positive message the Yes camp was trying to put out throughout the referendum campaign, and which had been their increasingly winning strategy in elections since 2007 (Mitchell 2016: 92).

The No campaign echoed this focus on the practical implications of independence when appealing to the female vote. However, in contrast to the Yes campaign's emphasis on the transformative potential of independence, it played up the uncertainties tied to a break-away from the UK. For example, in a now infamous campaign advertisement entitled 'The Woman Who Made Up Her Mind', the Better Together campaign appealed to undecided female voters by featuring a working mother unswayed by promises of a better future in an independent Scotland who was unwilling to gamble with her children's future and would thus vote No (Wilkinson 2014). Accusations of sexism soon followed, to which the campaign's response was that these were verbatim the words of women they had canvassed. ${ }^{3}$ While the advertisement's portrayal of women was 
indeed stereotypical and patronising, it is also worth noting that these types of arguments - cautionary and rational in the eyes of some, negative and amounting to scaremongering in the eyes of others characterized the entire No campaign in general and not just its appeals to women voters. The perception of the No side as engaging in negative campaigning - 'Project Fear', as Better Together's own communications director had himself referred to their campaign - was amplified by its inability to promote a coherent positive message (Mitchell 2016: 92).

Thus, despite a quite recent and rich tradition of alliance-building and agenda-setting activities tying gender equality to devolution, Scottish women initially engaged reluctantly with the independence debate. The Yes and No campaigns realized the potential of women voters to swing the result and appealed to their (real or supposed) interests: their presence in the workforce, family care, social benefits, but also their presumed risk aversion and concern about economic instability in the aftermath of independence. The long-running gender gap with regard to support for independence remained on voting day as well: men were still more likely to vote for independence than women, at a ratio of 53.2 per cent compared to 43.4 per cent (Mullen 2016: 12).

There is also another legacy of the 2014 referendum. The high levels of participation and political engagement seen among the broad population, including among women, show signs of having staying power in post-referendum politics. It has been argued that the high levels of grassroots mobilization, particularly on the Yes side, increased women's appetite for political activity (Rummery 2015). This could be contrasted to Catalonia, where the engagement of the women's movement with territorial politics has remained low, for a variety of reasons (Verge and Alonso 2015). The opportunity to place gender equality on the constitutional agenda of a newly independent country, coupled with the appeal of specific policy promises has been said to have politicized Scottish women in the long run as well (Rummery 2015). As mentioned, Women for Independence continues its activities, with a platform that includes greater representation for women in public and political life, gender equality and social justice alongside Scottish independence and other constitutional reforms. This outcome is not limited to the Scottish experience with an independence referendum. Following Quebec's close 1995 secession referendum, Québécois women also became more politicized, looking to embed gender equality in their constitution and to achieve concrete policy outcomes such as universal childcare that had been promised to them during the referendum campaign (Rummery 2015). In short, whatever the actual outcome of a high-stakes constitutional referendum, the visibility and levels of engagement of women 
during the campaign are likely to influence their political presence and expectations for change after the referendum as well.

\subsubsection{The 2012-14 Irish Constitutional Convention}

Ireland's experiment with a constitutional convention took place between 2012-14, when the Government set up such a body to deliberate upon and make recommendations concerning a set of constitutional reforms. ${ }^{4}$ The Convention was to consist of 100 members, two-thirds of whom were to be 'regular citizens' and a third of whom politicians, plus an appointed President. The 33 politicians were appointed by political parties based on their representation in parliament, and Northern Irish parties were also invited to participate, with one representative each. The 66 non-politicians were to be 'citizens entitled to vote at a referendum, randomly selected so as to be broadly representative of Irish society' and who volunteered to take part in the convention once contacted. In practice, this meant resorting to a statistical model of representation that was stratified to ensure the geographic representation of members, followed by quotas in relation to age within gender, socio-economic status and working status. A 'shadow' panel was similarly selected. In the end, the Convention had 49 female members, 33 selected randomly and 16 appointed by political parties. Scholars involved in the Convention process have noted that efforts were made to ensure the Convention's inclusion was not just external, as seen in the recruitment procedures and rules employed, but also internal, concerning internal participation of members, the composition of small group deliberations, and decisionmaking rules (Harris et al. 2015). In other words, it appears that attempts were made to engender not just the membership of the Convention, but also all of its deliberations.

The Convention, which was initially meant to run for a period of 12 months, was to produce reports on eight issues listed in its terms of reference. Among these issues, two referred to women: 'amending the [Constitution's] clause on the role of women in the home and encouraging greater participation of women in public life' and 'increasing the participation of women in politics'. The Government committed to responding to the Convention's reports within four months as well as to indicating a time frame for submitting accepted recommendations to a referendum. The Convention delivered its recommendations in March 2014, having extended its mandate by an additional three months and covered all initial issues and two additional ones (reform of the lower house of parliament and economic, social and cultural rights). The response from the Government was mixed, and of the two constitutional 
amendments submitted for a referendum, so far only one has been successful - the referendum on the constitutional recognition of same-sex marriage, held in 2015. Other Convention reports were met with more scepticism, were said to require more study or were effectively shelved.

The Convention tackled the issues related to women during one weekend in February 2013, when it deliberated upon submissions from the public, academics and legal experts, and advocacy groups. A 'large interactive panel discussion' followed these presentations, as well as small roundtable discussions, during which Convention members exchanged views and teased out details on the topics at hand..$^{5}$ It is useful to unpack the debates on the two issues separately, the main actors involved, as well as the alternatives and eventual outcomes of each.

The role of women in the home is explicitly mentioned in the Irish Constitution, Article 41.2 of which states:

41.2.1 In particular, the State recognises that by her life within the home, woman gives to the State a support without which the common good cannot be achieved.

41.2.2 The State shall, therefore, endeavour to ensure that mothers shall not be obliged by economic necessity to engage in labour to the neglect of their duties in the home.

Attempts to amend the Article had dated back long before the 2012 establishment of the Constitutional Convention. ${ }^{6}$ The Article's detractors pointed to its use not in empowering women but in relegating them to the private sphere and discriminating against women (especially mothers) in employment; they also argued that the Article no longer reflected the reality of Irish society. ${ }^{7}$

The Convention received submissions from a number of individuals and organizations on this issue, including from: Women for Election; Curam (an Irish non-governmental organization seeking recognition and support for the unremunerated work of parents and carers); the Iona Institute (a socially conservative Catholic advocacy group); the National Women's Council of Ireland; Union of Students in Ireland; the 5050 Group (a non-aligned group advocating equal gender representation in politics); and the University College Dublin Women's Graduates Association. ${ }^{8}$ Many of these submissions invoked the different era of adoption of the Article, referring to it as 'outdated and discriminatory', 'essentialist and sexist' or amounting to 'state-supported gender stereotyping'. They also emphasized the symbolic role of the Article as exclusionary of women outside the home and detrimental to carers of a different gender. Others, such as the Iona Institute, claimed it had not solely been the 
Catholic Church supporting the adoption of this Article, that the Article in fact pursued the recognition of domestic work, and that it acted as a safeguard for those women who choose to stay in the home: 'What the provision does is to set out our respect for the private sphere. It says that the marketplace cannot be all-dominant, that other spheres of life are also important, and sometimes more important' (Iona Institute 2013). ${ }^{9}$

The latter point was questioned by one of the two academics also addressing the Convention on this issue, who pointed out that while this reading of Article 41.2 was plausible, in fact the provision had been rejected by the courts as the basis for a rights claim regarding women's care work. ${ }^{10} \mathrm{~A}$ point of agreement emerging from multiple submissions was the need to render references to carers gender-neutral so as to reflect the reality of the domestic role of both women and men. Several of the submissions had called for the expansion of the type of care covered by the provision to include care for elders or care provided by other family members. Questions were also raised as to whether the role of women should be defined by the Constitution at all.

With regard to the second issue before the Convention, the submissions and presentations largely emphasized the gender gap that exists in terms of levels of participation in public and political life. One of the academics explained that Article 40.1 of the Irish Constitution, which provides that 'all citizens shall, as human persons, be held equal before the law', had been interpreted by the Supreme Court so as to include gender equality. Nevertheless, the specific references to women's role in the home in Article $41.2 \mathrm{had}$, as a practical effect, 'to interpret women's citizenship as being one of engagement in the private sphere of home and family life. The silence of the rest of the Constitution on civic participation more generally means that the basic context for shaping women's engagement in public life is absent. ${ }^{11}$ Despite high levels of participation of women in voluntary associations and despite legislation on candidate gender quotas, Yvonne Galligan explained, women's participation in decision-making structures remained low.

The submissions received similarly emphasized the gender gap in Irish political and public life, with several organizations noting the opportunity before the Convention to champion the issue. Women for Election, for example, suggested a possible new sub-section to the Constitution that would state: 'The State acknowledges that true democracy is inclusive of all its citizens. The State shall endeavour, by appropriate means, to promote equality in politics' (Women for Election 2013). The National Women's Council of Ireland called for a move towards a more participatory model of democracy, which would encourage higher levels of involvement of both women and men (National Women's Council of 
Ireland 2013: 3). The 5050 Group, however, pointed to existing legislation and deemed it to provide 'an appropriate mechanism for addressing the issue of the under-representation of women in Irish politics. No constitutional changes are necessary to enable the adoption of such a measure' (The 5050 Group 2013: 5).

The ensuing discussion in the Convention engaged with all these issues, although we do not have accounts of the small-table deliberations, which remained unrecorded except for the note-takers' reports. The Convention members voted overwhelmingly in favour of amending Article 41.2 (88 per cent), with only a minority expressing the view that the Article should be deleted entirely (12 per cent). There was nearunanimity in favour of the motion that the Article should be rendered gender-neutral so as to include other carers in the home (98 per cent), while a narrower majority (62 per cent) supported the clause being amended to include carers beyond the home. There was no clear position emerging on the level of support the state should provide to carers covered by this provision, with the average indicating that members favoured a reasonable level of state support. On the second topic of increasing women's participation in political and public life, a majority favoured the introduction of an explicit gender equality provision in the Irish Constitution (62 per cent). Votes were evenly split on whether there should be a constitutional duty on the state to take positive actions to enhance women's participation (49 per cent saying yes, 50 per cent saying no and one per cent remaining undecided). There was again near-unanimity (97 per cent) among members on wanting to 'see more government action to encourage greater participation of women in politics and public life' outside the Constitution. Finally, a strong majority of the Convention supported the amendment of the Constitution to include gender-inclusive language ( 89 per cent).

The Irish Government's response to the Convention's report on these issues was positive on the surface, welcoming its general recommendation on amending the provision on the role of women in the home (Dail Eireann Debate 2013). The Minister for Justice and Equality, presenting the Government's response to the parliament, refused to indicate a timeframe for a referendum on implementing any changes, however, because it considered 'the issue of carers' to require further investigation. He indicated that a special taskforce would be needed to look at the issue. With regard to amendments to Article 40, he 'accept[ed] the recommendation of the convention that the Constitution should not be amended to address the role of women in political and public life'. ${ }^{12}$ The Minister then listed other initiatives, including legislative amendments already in preparation, which pursued the goal of increasing women's 
participation in public life. The Minister indicated that a review would be initiated and a reasoned response would be brought back within a year's time on the question of adopting an explicit gender equality clause in the Constitution. Finally, on the topic of rendering constitutional language gender-inclusive, the Minister again indicated that more analysis was needed, given that 'if implemented, it may require extensive textual amendments to the Constitution' and mandated a 'preliminary feasibilityscoping study'. Thus, despite much lip-service paid to the importance of the Convention's work and of advancing gender equality more generally, the Irish Government's concrete measures in response were mostly lacking. A January 2016 review of the status of the Government's action on the Convention's reports found 41 per cent of the body's recommendations to have been 'parked', including those on women (Farrell 2016).

\subsubsection{The 2011-14 Tunisian Constitution-making Process}

Tunisia's 2014 Constitution was drafted during an intensive and prolonged process, following the ousting of President Ben Ali and the so-called 'Jasmine Revolution' of January 2011. While the revolution's impetus came from dissatisfaction with the economic situation, regime corruption and police brutality, women's rights issues quickly came to the fore of the country's first post-revolution elections: the elections for the Constituent Assembly held in October 2011 (Marks 2013: 224). Monica Marks has argued that already at that stage of the process, women's rights were invoked as 'a useful wedge issue - one that could deflect attention from hastily constructed economic programs and isolate electoral opponents as either "too secular" or "too Islamist" to please the population at large' (Marks 2013: 224). The Tunisian experience provides lessons on the interaction between a participatory constitution-making process and the advancement of women's rights in a new key. The context of transition from authoritarian rule to democracy provided both challenges and opportunities for women's constitutional gains, and continues to shape the gender outcomes of Tunisia's post-revolutionary period. As Georgina Waylen has observed, in such transitions, these outcomes must necessarily be evaluated contextually and relative to the status quo ante (Waylen 2007: 38), and Tunisia's case is no different.

Among the first sites of struggle for women seeking to engender the constitution-making process in Tunisia were the elections to the Constituent Assembly. Already in May 2011, a parity law had been passed requiring political parties to put forth electoral lists consisting of 50 per cent women, alternating their name in a so-called 'zipper system' (Marks 
2013: 235). Many political parties did not abide by this rule, whereas the major Islamist party Al-Nahda did. This resulted in 42 of the 49 women elected in the Constituent Assembly belonging to Al-Nahda, a situation already challenging easy assumptions about what implications Tunisia's Islamist-secular divide would have on women's political representation. Having 49 women elected to the Assembly, representing 24 per cent of its members, was certainly a significant departure from past constitutionmaking moments in Tunisia and also represented the largest representation of women in any parliament in the Arab world at the time (National Democratic Institute for Democratic Affairs 2014: 8).

Heavy expectations loomed over the Constituent Assembly, which simultaneously had to draft a new fundamental law and act as a transitional legislative body. Opinions differed widely as to how long the Assembly had to deliberate, although in the end it completed its work in two years. The final Constitution was adopted in January 2014 by a two-thirds majority of the Assembly but was not submitted to a popular referendum. It would bring to an end what some have seen as a period of 'extraordinary politics' whereby the Tunisian people actively reconstituted society (Zemni 2015: 2).

Among other elements, the drafting process was notable due to the efforts to involve the public. Focus groups conducted before the Assembly began its deliberations warned that it needed to 'listen to the people' and 'should not forget what happened to [ousted President] Ben Ali; the Tunisian people revolted once and can do so again' (Gluck and Brandt 2015: 7). Moreover, a February 2013 poll 'showed that 80 percent of Tunisians wanted to be able to vote on the constitution at referendum, a contingency that was available only if the Constituent Assembly failed to approve the draft by a two-thirds majority vote' (Gluck and Brandt 2015: 7).

The initial drafting stages appear to have been less inclusive, but transparency and public involvement were pursued following the publication of the first draft in August 2012 (Gluck and Brandt 2015: 8). Once a second draft was published, these efforts intensified. A two-month outreach campaign was launched that included public meetings in the Assembly members' constituencies, hearings with interest groups and television broadcasts of most Assembly proceedings, and the United Nations supported a dialogue between Assembly members and citizens and civil society organizations in all of Tunisia's governorates (Gluck and Brandt 2015: 10). Estimates are of 6000 citizens, 300 civil society organizations and 320 university representatives having provided input directly to Assembly members. This input seems to have had a direct bearing on certain changes to the Constitution's text, including on issues 
such as guarantees of the separation of powers and of the right to vote, state involvement in religious practice and constitutional language on women (more on the latter below) (Gluck and Brandt 2015: n 44-45). Moreover, civil society representatives were involved in brokering compromise between political parties and thereby overcoming a majoritarian political dynamic in the Assembly (Gluck and Brandt 2015: 10). However, poor planning, inadequate resources and, to an extent, a lack of understanding of the role public participation could play also led to failings in the process, particularly in its early months (The Carter Center 2015: 68-71).

One of the tensest episodes of the Tunisian constitution-making process occurred with the publication of the first draft of the new constitution, in August 2012. ${ }^{13}$ Article 28 in that draft referred to equality between women and men in these terms:

The State shall guarantee the protection of the rights of women and shall support the gains thereof as true partners to men in the building of the nation and as having a role complementary thereto within the family.

The State shall guarantee the provision of equal opportunities between men and women in the bearing of various responsibilities. The State shall guarantee the elimination of all forms of violence against women.

The reference to women as 'true partners to men', with a 'complementary' role within the family was immediately criticised both by Tunisian feminists and by international observers. It did not help that earlier leaks and translations of the official Arabic text had rendered the phrase as 'men's complements' or 'men's associates' (Marks 2013: 236). On 13 August 2012, an estimated 7000 people protested against Article 28 in Tunis; public figures spoke out in favour of revising the provision; and international organizations including the United Nations expressed concern that 'the draft text places women on unequal footing with men and does not consider them as independent, full individuals' (Marks 2013: 237, United Nations Working Group on Discrimination against Women in Law and in Practice 2012).

Members of the Constituent Assembly responsible for drafting the provision defended it, blamed erroneous translations for the misunderstandings, and pointed to Article 22 of that same draft as a general guarantee of equality meant to prevent discriminatory interpretations of Article 28. ${ }^{14}$ Nevertheless, the relational language used in Article 28 had left room for ambiguity, at best, and had exacerbated fears of a project to curtail women's rights hidden behind the constitution-making process, at worst. The Constituent Assembly set about revising the provision and 
sought input from citizens and civil society by way of a consultation mechanism on its official website and two days of discussion with non-governmental organizations in September 2012 (Marks 2013: 237). Article 46 in the final Tunisian Constitution employs much clearer language in protecting women's rights, guaranteeing equality of opportunities and obliging the state to work towards parity in elected assemblies and towards eradicating violence against women.

The Tunisian case is thus seemingly one of successful mobilization of women's rights groups when faced with the possibility of the constitution-building process undermining women's status (Charrad and Zarrugh 2013). Indeed, it has been praised for bringing closer together drafters, civil society and women's rights activists and for helping to develop the latter's capacity as actors in the transition (Mnsari 2013: 13). However, it would be a mistake to view women's gains in the new Constitution as the end of the struggle for advancing gender equality and non-discrimination in post-revolutionary Tunisia. Several obstacles remained at the time of the adoption of the permanent Constitution in January 2014. Foremost among these was the need to reform the Personal Status Code, a 1956 law mixing French civil law and Sharia jurisprudence which enjoys widespread support in Tunisia (Marks 2013: 238). While the Code is progressive in the Arab world on a number of issues (including its regulation of divorce and polygamy), its stance on issues such as inheritance and child custody rights remains discriminatory against women.

Another important fight ahead for Tunisian women's rights activists is judicial reform, including guarantees of judicial independence and a functioning constitutional court able to enforce the new protections enshrined in the Constitution. Other measures, such as reform of the security sector and the establishment of transitional justice mechanisms, will also have gendered impacts (Marks 2013). Thus, while the Tunisian constitution-making process in many ways proved responsive to women's demands, the new Constitution is but one of a number of steps - the beginning of what Dobrowolsky and Hart have termed the "constant vigilance and the hard grind of sustained activism' (2004: 3) - needed to ensure the new democracy also becomes a truly gender-sensitive one.

\subsection{DOES PARTICIPATORY CONSTITUTION-MAKING DELIVER FOR WOMEN?}

Several observations can be made based on the cases above. One is that it is difficult to evaluate the success of participatory constitution-making for 
women, given the lack of clarity on how to define the success of these mechanisms in general. In the case of referendums, success may seem easier to measure: turnout on the day of voting. However, we have come to understand that this is too blunt a measure of a referendum's success, eliding nuance, and open to manipulation by political elites. One element easily missed in such macro-evaluations of referendum outcomes is precisely the role played by women throughout the process: from the decision to hold a referendum at all, through the campaign and up until voting day.

As the Scottish referendum analysis above has shown, it is not just the raw numbers of women taking part in debates and voting that matter, but also the nature and reach of their mobilization and the impact of their voice on deliberations. Viewed in this light, the 2014 Scottish independence referendum may be seen as a story of partial success for women's participation, and one which, in the end, challenged assumptions about women's interest and capacity to engage in processes of grand-scale constitutional change. Nevertheless, the Scottish case is also instructive on how easy it can be for constitutional reform to fail to engage women, or to attempt to do so by resorting to stereotyping. Grassroots mobilization and concerted efforts to put women's interests on the policy agenda are needed, as is the promotion of women's participation as a matter of democratic right in any decision-making process in the polity. The cases of Scotland and Quebec illustrate how referendums can provide women with opportunities to push for gender equality more broadly and to inscribe it into the post-referendum agenda as well.

Success is also difficult to delineate in the case of micro-deliberative participatory forums such as the Irish Constitutional Convention. If the Convention is to be evaluated purely on whether it completed its work and fulfilled its mandate, then it can indeed be seen as a success story. If we factor in concrete reforms passed as a result of the Convention's recommendations, the scope for optimism narrows. The Irish Government's response to the Convention's work has been mixed and while the 2015 same-sex marriage referendum returned a favourable result, it remains the only issue tackled by the Convention to have yielded concrete constitutional change. (It also remains questionable whether a popular vote was the best way to seek to give more rights protection to a historically discriminated group.) While the requirement for constitutional amendments to be subjected to popular referendums is a feature integral to the Irish system, it nevertheless is true that constitutional conventions of the type discussed in this chapter have, in all areas, been consultative rather than decision-making bodies. In other words, they are set up to deliberate and make recommendations upon constitutional 
reforms, but the implementation of their recommendations reverts back to the political process. Thus, implementation will be subject to the vagaries of political will and changing political landscape. ${ }^{15}$ That is not a criticism of the constitutional convention model as much as an appreciation of its limitations - while it can provide deliberative legitimacy to certain proposals for change, the final enactment of that change will rest with more traditional institutions.

In the case of Tunisia, it was not only the problematic language in Article 28 that was revised in the final text of the Constitution. Other concessions made by the Islamist Al-Nahda, the largest party in the Constituent Assembly, included omitting references to Sharia as a source of legislation. While other references to Islam remain in the 2014 Constitution, they are present alongside a text which at least nominally endorses women's rights and sets out guarantees for their protection. Evaluating these achievements, however, is confounded by the difficulties in predicting the success of the new Constitution. The extent to which gains for women's rights in Tunisia remain ink on paper or are enforced in practice will depend on a host of other factors, including the political will behind establishing powerful institutions to implement the constitution and promote individual rights. The nearly two-year delay in establishing the Constitutional Court, which the Constitution mandates, is not an encouraging sign in this regard. And, while the Truth and Dignity Commission established in 2014 includes a Women's Committee tasked with focusing specifically on the former regime's crimes against women, the constant attacks and pushback against the Commission make the pursuit of transitional justice significantly more challenging. These do not detract from the gains of Tunisian feminists in engendering their constitution, but do highlight the need for continued vigilance and activism if these gains are not to be undone.

A second aspect worth highlighting in the case of referendums, constituent assemblies with popular consultations and constitutional conventions is the question of the quality of the deliberations involved in all three. Increasingly, those working on referendums have come to view even high levels of participation as insufficient markers of success and have called for the quality of deliberations to be taken into account. ${ }^{16}$ For example, it would be useful to learn to what extent women's participation influenced the agenda and tone of the referendum campaign in Scotland, and whether their input led to changes in voter options (among both women and men). Moreover, while the overall referendum process was deemed to have been deliberative (Tierney 2014a), it would be instructive to break down data - such as on perceptions of respect and on loser consent to the referendum result - by gender. 
By contrast, the constitutional conventions discussed in this chapter have, from the outset, been modelled with clear awareness of the need for gender balance that would extend beyond membership selection. In Iceland, convention members themselves chose to adopt a consensus decision-making rule and in Ireland, as noted above, attempts were also made to ensure the gender-sensitivity of mechanisms for the internal participation of convention members. Such steps were informed by the growing scholarly understanding of the sometimes surprising ways in which deliberation is gendered (Karpowitz et al. 2012).

Finally, Tunisia's process was less structured and as such makes it more difficult to appraise the quality of debates in the public consultations held. It does seem to have been intensely polarized, however, between the older, secularized feminist organizations concentrated in the cities and the newer, religious and often rural organizations and Al-Nahda activists (Marks 2013: 241). The distrust and deep-seated resentments between these groups did not derail the constitution-building process but may have a more substantial impact in its aftermath. The growing inequalities in Tunisian society and the disparities in socio-economic prospects of its different strata may also exacerbate the differences between its feminist groups in the coming years.

A third point relates to the type of mechanism employed to give the people a voice on constitutional matters and the impact of this choice on women's participation. The large-scale nature of constitutional referendums will mean that engagement will differ, potentially widely, according to factors such as the question raised, the prominence of a gender equality agenda or clear links to women's interests, the visibility of women leaders during the campaign, the effectiveness of women's organizations to mobilize and build alliances, the willingness of political parties to come together on gender equality issues, and more. The resources allocated for running the referendum campaign will affect the quality and quantity of information provided to citizens and the avenues at their disposal to engage in discussion of the issue. The timeframe for a referendum also severely impacts on the quality of the deliberations that can take place in the run-up to the vote, as well as on the ability of different groups and organizations to mobilize members and attempt to influence voters. All of these can have a gendered impact. As the Scottish case has shown, these various aspects can be managed successfully, although even there, concerns for maximizing women's involvement came relatively late in the campaign.

Similar considerations also apply to constitutional conventions. The method of selection will be crucial in determining the representativeness of the body. In Ireland, the method of selecting non-politician members 
of the Convention was statistical, with gender parity a key aim; politician members were appointed in such a way that the final make-up of the Convention achieved gender balance. Another model was used in Iceland, where the membership of the constitutional convention was determined based on direct elections, with a 40 per cent gender neutral quota in place in case results had yielded a gender imbalance among its members (ultimately the quota was not needed). More problematic might be situations where civil society organizations are to be represented in the constitutional convention. ${ }^{17}$ Such representatives would have to be chosen so as to reflect a diversity of societal views, with the choice likely to always exclude some. Furthermore, if the convention were tasked with deliberating on divisive issues such as abortion, it is difficult to envision any representative of a group opposing abortion maintaining a willingness to change his or her mind on the issue - a precondition for true deliberation to occur. ${ }^{18}$

In Tunisia, the constitution-building process was set in motion relatively rapidly following the Jasmine Revolution - elections for the Constituent Assembly were held within months of the ousting of Ben Ali and the body began its work that same year. The proportional representation system used to allocate seats made sense in the context of a country learning to navigate the waters of multiparty politics. In regards to the participatory elements of the Tunisian process, however, these seem to have been added on as the drafting developed. While they seemingly succeeded in engaging large numbers of citizens and civil society organizations, there is no denying that more advanced planning and resource allocation could have maximized the process's participatory gains. Lastly, a referendum was not resorted to as the final certification stage in the constitution-making process, which was instead achieved by a two-thirds vote in the constituent assembly. This choice was likely a consequence of the country's fraught experience with plebiscites under the former authoritarian regime and of a desire not to risk seeing the gains of the long drafting process undone.

This leads to a final question worth asking here: whether all matters of constitutional change can or should be subject to popular input and if not, what the discerning criteria should be. This issue has only recently come to be highlighted in constitutional scholarship on constitutional conventions, tempering some of the initial enthusiasm in the aftermath of the successful referendum on Iceland's 'crowdsourced constitution' and of the completion of the work of the Irish Constitutional Convention. ${ }^{19}$ In contrast, referendum scholars have long cautioned against the threat of majoritarian capture of referendums and their potential negative impact 
on minorities (Gamble 1997). This is especially concerning when looking at participation through a gender-sensitive lens.

While the cases above provide largely positive examples of participatory mechanisms' potential to empower women and to champion a gender equality agenda, there are also instances where appeals to the people have been detrimental to women. In 2016, for example, four amendments to the Constitution of Bahamas aimed at ensuring gender equality with regard to citizenship were defeated in a national referendum (Caribbean 360 2016). The experience with referendums on 'moral issues' such as the decriminalization of abortion or reform of divorce law in countries such as Ireland and Italy is not optimistic for the propensity of plebiscites to advance gender equality (Qvortrup 2005: 77-85). In Poland, a popular initiative to adopt a total ban on abortion was defeated in 2011, but a second such initiative, strongly backed by the Catholic Church, was launched in 2016 (Grzymala-Busse 2016). One could also imagine a constitutional convention making recommendations that would not advance the cause of gender equality, especially in more conservative societies which, under a statistical model of membership selection such as was used in Ireland, the convention would have to mirror. Public consultations may not be binding on decision-makers, but they can be relied upon and manipulated to support conservative positions on gender equality and may imbue them with the veneer of popular legitimacy.

\subsection{CONCLUSION}

This chapter has investigated the extent to which much-lauded participatory constitution-making mechanisms such as referendums, constitutional conventions, and constituent assemblies with popular consultations have included women as equal participants. By looking at the cases of the 2014 Scottish independence referendum, the 2012-14 Irish Constitutional Convention, and the 2011-14 Tunisian constitution-making experience, the chapter has first sought to evaluate the degree of women's participation in these processes. With respect to the Scottish referendum, it has analysed the nature of the mobilization women and women's groups have engaged in, the types of arguments to which they were addressed and have resonated, and the potential reasons for the persistent gender gap in support for independence. In the case of the Irish Convention, it has looked at the selection method of that body as well as at the substantive issues raised during deliberations on the constitutional role of women and their participation in public and political life. The lack of concrete action 
by the Irish Government in response to the Convention's recommendations for constitutional reform on these matters was also highlighted. Finally, the Tunisian experience with popular mobilization and consultations during the drafting of the 2014 Constitution was invoked as an example of efforts to engender democratic transitions. The make-up of the Constituent Assembly, the deployment of civic energies to oppose discriminatory language in an early draft, and the method of adoption of the fundamental law all had a bearing on the gains for gender equality in Tunisia's new constitution.

Based on these examples, the chapter considered whether participatory constitution-making mechanisms ultimately deliver for women. In so doing, it first emphasized that determining success in these processes, in general, as well as when it comes to women's participation, is more complex than might initially appear. Nevertheless, the chapter has argued that evaluations of success in the case of referendums, constitutional conventions, and constituent assemblies with popular consultations need to go beyond raw numbers and should take into account the quality of popular deliberation and the presence and impact of women's voices therein. Finally, it has warned against too quick a recourse to the people on matters of constitutional significance, pointing to the possibility that such participatory instruments may be abused or simply ill-suited to advancing the cause of gender equality. Thus, careful institutional design and comparative learning remain necessary in order to ensure that participatory mechanisms do indeed empower rather than fetter women as agents of constitutional change.

\section{NOTES}

1. See, for example, the February 2016 referendum on the expulsion of foreigners (the 'Implementation Initiative' or 'Durchsetzungsinitiative') in Switzerland.

2. The scrapping of Trident and redirection of the funds towards childcare appealed to anti-nuclear and pro-women's rights groups, including the Scottish Greens and the Scottish Socialist Party, and was linked to the historic 'Bairns, Not Bombs' rallying cry (Rummery 2015).

3. It is worth noting, however, that the lack of a female-friendly message from Better Together had been signaled before the video campaign, including by unionist supporters. Baroness Vadera, a former UK Minister, had described the No side as being 'run by grumpy old men' in a referendum campaign in which 'the really undecided voters are women' (The Herald, Scotland, 24 June 2014).

4. The following description of the Convention is based on the Terms of Reference of the Constitutional Convention, Resolution of the Houses of the Oireachtas of July 2012.

5. Second Report of the Convention on the Constitution, The Convention on the Constitution, May 2013. 
6. See discussion in the Report of the Constitution Review Group, Dublin, Stationery Office 1996.

7. See academic presentations to the Convention included in the Second Report of the Convention on the Constitution, which also discuss the history of this constitutional provision and relevant case law surrounding it.

8. For all submissions received by the Convention, see https://www.constitution.ie/ submissions.aspx. Accessed 6 March 2017.

9. This view was echoed in part by Curam (2013), which argued that Article 41.2 helped protect domestic carers and that any amendment should only strengthen this protection: "Article 41.2 represents a key instrument for supporting families in a variety of domains and situations and it forms the basis for legal, tax and social welfare provisions of benefit to parents and carers on a full- or part-time basis.'

10. Presentation by Professor Siobhan Mullally, included in the Second Report of the Convention on the Constitution. Mullally also pointed out that the Constitution did not include references to any roles or societal functions attributed to other private individuals, that it failed to recognize the variety of women's roles, and that Article 41.2 did not recognize the role of men or fathers.

11. Presentation by Professor Yvonne Galligan, included in the Second Report of the Convention on the Constitution.

12. His phrasing oversimplified the Convention's position on this question, given that members had been split almost evenly on the question of a constitutional duty on the part of the state to adopt positive measures towards improving the participation of women.

13. For an unofficial translation of the first draft of the Tunisian Constitution, dated 14 August 2012, see http://www.constitutionnet.org/files/2012.08.14_-_draft_ constitution_english.pdf. Accessed 6 March 2017.

14. Article 22 of the first draft of the Tunisian constitution read: 'Citizens shall, before the law, be equal in rights and obligations without any discrimination of any form.'

15. In fact, several precursor conventions to the Irish Constitutional Convention saw their recommendations shelved or defeated at least in part due to waning political support. The draft constitution delivered by the Icelandic Convention was approved in a national referendum in 2012, but was eventually shelved during the necessary parliamentary process to adopt it. The non-implementation of recommendations on electoral change made by the citizen assembly in The Netherlands has also been attributed, at least in part, to political changes which deprived the assembly of support. For a discussion of these issues, see Suteu 2015.

16. On the deliberative potential of constitutional referendums, see Tierney 2012. For an analysis of the differences and overlap in goals and principles underlying participatory versus deliberative mechanisms for constitutional change, see Suteu and Tierney (forthcoming).

17. Interestingly the Scottish Government had indicated that such organizations would be represented in the constitutional convention that it would have set up to draft the constitution of an independent Scotland.

18. Incidentally, in 2016 several Irish politicians including the Prime Minister expressed support for setting up a second constitutional convention to deal with changes to the country's abortion law (RTE News 27 November 2015).

19. For an analysis questioning whether a constitutional convention could provide solutions in the quest to reform the UK constitution, as advocated in the aftermath of the 2014 Scottish referendum and the initial perceived success of the Irish Constitutional Convention, see Suteu 2016. 


\section{REFERENCES}

The 5050 Group (2013), Submission to the Constitutional Convention on the Role of Women/Women in Politics, February 2013.

Arato, Andrew (1995), 'Forms of Constitution Making and Theories of Democracy', Cardozo Law Review 17(2): 191.

Arato, Andrew (2012), 'Conventions, Constituent Assemblies, and Round Tables: Models, Principles and Elements of Democratic Constitution-making', Global Constitutionalism 1(1): 173.

Bell, Christine and Fiona MacKay (2013), 'Women and Constitutional Debates: Engendering Visions of a New Scotland', Scottish Constitutional Futures Forum Blog, 25 February 2013, http://www.scottishconstitutionalfutures.org/OpinionandAnalysis/View BlogPost/tabid/1767/articleType/ArticleView/articleId/1169/Christine-Bell-and-FionaMacKay-Women-and-Constitutional-Debates-Engendering-Visions-of-a-New-Scotland. aspx. Accessed 6 March 2017.

Bergsson, Baldvin and Paul Blokker (2014), 'The Constitutional Experiment in Iceland', in Ellen Bos and Kalman Pocza (eds), Verfassunggebung in konsolidierten Demokratien: Neubeginn oder Verfall eines Systems?, Nomos 2014, 154.

Brown, Alice (2001), 'Taking their Place in the New House: Women and the Scottish Parliament', in Esther Breitenbach and Fiona Mackay (eds), Women and Contemporary Scottish Politics: An Anthology, Polygon at Edinburgh University Press, 197.

Cairney, Paul (2015), 'The Scottish Independence Referendum: What are the Implications of a No Vote?', Political Quarterly 86(2): 186.

Carey, John M. (2009), 'Does It Matter How a Constitution Is Created?', in Zoltan Barany and Robert G. Moser (eds), Is Democracy Exportable?, Cambridge University Press, 155.

Caribbean360 (2016), "Voters in Bahamas Say "No" to Gender Equality Changes in Constitution', 8 June 2016, http://www.caribbean360.com/news/voters-bahamas-say-nogender-equality-changes-constitution. Accessed 6 March 2017.

The Carter Center (2015), The Constitution-making Process in Tunisia: Final Report 2011-2014, 15 April 2015, http://www.cartercenter.org/news/publications/peace/ democracy_publications/tunisia-peace-reports.html. Accessed 6 March 2017.

Charrad, Mounira M. and Amina Zarrugh (2013), 'The Arab Spring and Women's Rights in Tunisia', E-International Relations, 4 September 2013, http://www.e-ir.info/2013/09/ 04/the-arab-spring-and-womens-rights-in-tunisia/. Accessed 6 March 2017.

Curam (2013), Submission to the Convention on the Constitution: Article 41.2, February 2013.

Curtice, John (2014), 'So Who Voted Yes and Who Voted No?', What Scotland Thinks, 26 September 2014, http://blog.whatscotlandthinks.org/2014/09/voted-yes-voted/. Accessed 6 March 2017.

Dail Eireann Debate (2013), Second Report of the Convention on the Constitution: Statements, Vol. 816 No. 3, 10 October 2013.

Dobrowolsky, Alexandra (2003), 'Shifting States: Women's Constitutional Organizing across Time and Space', in Lee Ann Banaszak, Karen Beckwith and Dieter Rucht (eds), Women's Movements Facing the Reconfigured State, Cambridge University Press, 114.

Dobrowolsky, Alexandra and Vivien Hart (eds) (2004), Women Making Constitutions: New Politics and Comparative Perspectives, Palgrave MacMillan.

Draft of the Constitution of the Republic of Tunisia (2012), 14 August (unofficial translation), http://www.constitutionnet.org/files/2012.08.14_-_draft_constitution_english. pdf.

Elkins, Zachary, Tom Ginsburg and James Melton (2009), The Endurance of National Constitutions, Cambridge University Press. 
Elster, Jon (1995), 'Forces and Mechanisms in the Constitution-making Process', Duke Law Journal 45: 364.

Elster, Jon (1997), 'Ways of Constitution-making', in Axel Hadenius (ed.), Democracy's Victory and Crisis, Cambridge University Press, 123.

Farrell, David (2016), 'Outcome of the Irish Constitutional Convention (as of January 23, 2016)', The Irish Politics Forum, 23 January 2016.

Farrell, David, Eoin O'Malley and Jane Suiter (2013), 'Deliberative Democracy in Action Irish-Style: The 2011 We the Citizens Pilot Citizens' Assembly', Irish Political Studies 28(1): 99.

Gamble, Barbara S. (1997), 'Putting Civil Rights to a Popular Vote', American Journal of Political Science 41(1): 245.

Gluck, Jason and Michele Brandt (2015), Participatory and Inclusive Constitution Making: Giving Voice to the Demands of Citizens in the Wake of the Arab Spring, United States Institute of Peace.

Grzymala-Busse, Anna (2016), 'Why Would Poland Make Its Already Strict Abortion Law Draconian?', The Washington Post, 18 April 2016, https://www.washingtonpost.com/ news/monkey-cage/wp/2016/04/18/why-would-poland-make-its-already-strict-abortionlaw-draconian/. Accessed 6 March 2017.

Harris, Clodagh, David Farrell and Jane Suiter (2015), 'It's Good to Talk! Inclusion, Equality and Deliberation: A Gendered Analysis of Ireland's Constitutional Convention', Paper presented at the Irish Citizens Decide: A Review of Ireland's Convention on the Constitution Conference, Newman House, Dublin, 13 November 2015.

The Herald (2014), 'Baroness Vadera: The Better Together Campaign Is Run by Grumpy Old Men', 24 June 2014, http://www.heraldscotland.com/news/13166955.Baroness_ Vadera_the_Better_Together_campaign_is_run_by_grumpy_old_men/. Accessed 6 March 2017.

The Iona Institute (2013), Submission to the Convention on the Constitution on Article 41.2, February 2013.

Karpowitz, Christopher, F. Tali Mendelberg and Lee Shaker (2012), 'Gender Inequality in Deliberative Participation', American Political Science Review 106(3): 533.

Kenny, Meryl (2014), 'Engendering the Independence Debate', Scottish Affairs 23(3): 323.

Klimes, Michael (2013), 'Scottish Independence: Nicola Sturgeon Pledges Jobs Boost for Women', International Business Times, 26 November 2013, http://www.ibtimes.co.uk/ nicola-sturgeon-alex-salmond-scottish-independence-economy-525292. Accessed 6 March 2017.

Landau, David (2013), 'Constitution-Making Gone Wrong', Alabama Law Review 64(5): 923.

Marks, Monica (2013), 'Women's Rights Before and After the Revolution', in Nouri Gana (ed.), The Making of the Tunisian Revolution: Contexts, Architects, Prospects, Edinburgh University Press, 224.

Mitchell, James (2016), 'The Referendum Campaign', in Aileen McHarg, Tom Mullen and Alan Page et al. (eds), The Scottish Independence Referendum: Constitutional and Political Implications, Oxford University Press, 75.

Mnsari, Anware (2013), 'The Constitution-Making Process in Tunisia: Women's Participation - Lessons Learned and Good Practices', in The Woodrow Wilson International Center for Scholars, Women's Participation: The Making of the Tunisian Constitution, http://www.50x50movement.org/sites/default/files/inline-files/report.pdf. Accessed 6 March 2017.

Mullen, Tom (2016), 'Introduction', in Aileen McHarg, Tom Mullen and Alan Page et al (eds), The Scottish Independence Referendum: Constitutional and Political Implications, Oxford University Press, 3. 
Murtagh, Cera (2013), 'Engendering Debate', Scotland's Referendem: Informing the Debate, 20 February 2013, http://www.referendum.ed.ac.uk/engendering-debate/. Accessed 6 March 2017.

National Democratic Institute for Democratic Affairs (2014), Tunisia's National Constituent Assembly: Gender Assessment, 21 March 2014, https://www.ndi.org/sites/default/ files/Tunisia-Gender-Assessment-National-Constituent-Assembly-ENG.pdf. Accessed 6 March 2017.

National Women's Council of Ireland (2013), Submission to the Constitutional Convention Meeting on the Topic: '(vi) ... Encouraging Greater Participation of Women in Public Life; (vii) Increasing the Participation of Women in Politics', February 2013.

Newman, Cathy (2014), 'Nicola Sturgeon: "Scottish Independence Lies in the Hands of Risk Averse Women"”, Telegraph, 17 September 2014, http://www.telegraph.co.uk/ women/womens-politics/11102520/Nicola-Sturgeon-says-Scottish-independence-lies-inthe-hands-of-risk-averse-women.html. Accessed 6 March 2017.

Qvortrup, Matt (2005), A Comparative Study of Referendums: Government by the People, $2^{\text {nd }}$ ed., Manchester University Press.

Rowe, Gene and Lynn J. Frewer (2005), ‘A Typology of Public Engagement Mechanisms', Science, Technology, \& Human Values 30(2): 251.

RTE News (2015), 'Taoiseach Would Call Forum on Abortion If Re-elected', 27 November 2015, http://www.rte.ie/news/2015/1127/749698-abortion/. Accessed 6 March 2017.

Rummery, Kirstein (2015), 'Why Women Have Become Politicised in Great Numbers', The Herald, 13 October 2015, http://www.heraldscotland.com/opinion/138425 80.Agenda_Why_women_have_become_politicised_in_great_numbers/?ref=fbshr. Accessed 6 March 2017.

Saunders, Cheryl (2012), 'Constitution Making in the 21st Century', International Review of Law 1(4): 1.

The Scottish Government (2013), Scotland's Future: Your Guide to an Independent Scotland, 26 November 2013.

Smith, Graham (2009), Democratic Innovations: Designing Institutions for Citizen Participation, Cambridge University Press.

Suteu, Silvia (2015), 'Constitutional Conventions in the Digital Era: Lessons from Iceland and Ireland', Boston College International \& Comparative Law Review 38(2): 251.

Suteu, Silvia (2016), 'Developing Democracy through Citizen Engagement: The Advent of Popular Participation in UK Constitution-Making', Cambridge Journal of International and Comparative Law 4(2): 405.

Suteu, Silvia and Stephen Tierney (forthcoming), 'Participation is Not Deliberation: Disentangling Principles of Constitution-making Good Practice', in Jeff King, Hoi Kong and Ron Levy (eds), Deliberative Constitutionalism, Cambridge University Press.

Terms of Reference of the Constitutional Convention (2012), Resolution of the Houses of the Oireachtas of July 2012.

Tierney, Stephen (2008), “We the Peoples": Constituent Power and Constitutionalism in Plurinational States', in Martin Loughlin and Neil Walker (eds), The Paradox of Constitutionalism: Constituent Power and Constitutional Form, Oxford University Press, 229.

Tierney, Stephen (2012), Constitutional Referendums: The Theory and Practice of Republican Deliberation, Oxford University Press.

Tierney, Stephen (2014a), “'And the Winner is ... the Referendum”: Scottish Independence and the Deliberative Participation of Citizens', I-CONnect Blog, 29 September 2014, http://www.iconnectblog.com/2014/09/and-the-winner-is-the-referendum-scottishindependence-and-the-deliberative-participation-of-citizens/. Accessed 6 March 2017.

Tierney, Stephen (2014b), 'Europe is Entering the "Age of the Referendum", But There is Nothing to Fear for European Democracy If Referendums Are Properly Regulated', 


\section{6}

Constitutions and gender

Democratic Audit, 22 October 2014, http://www.democraticaudit.com/?p=8777. Accessed 6 March 2017.

United Nations Working Group on Discrimination against Women in Law and in Practice (2012), 'Tunisia: UN Expert Group Calls on New Government to Protect and Strengthen Achievements on Equality and Women's Human Rights', 21 August 2012.

Verge, Tania and Alba Alonso (2015), 'The Gendered Dimensions of Constitutional Change: Women and the Independence Referendums in Scotland and Catalonia', Democratic Audit UK, 1 December 2015, http://www.democraticaudit.com/?p=17801. Accessed 6 March 2017.

Waylen, Georgina (2007), Engendering Transitions: Women's Mobilization, Institutions and Gender Outcomes, Oxford University Press.

Widner, Jennifer (2008), 'Constitution-writing in Post-conflict Settings: An Overview', William \& Mary Law Review 49(4): 1513.

Wilkinson, Michael (2014), 'Fury at "Sexist" Video from Better Together Campaign Aimed at Undecided Women Voters', The Telegraph, 27 August 2014, http://www. theguardian.com/politics/2014/aug/27/scottish-independence-better-together-campaignnew-advert. Accessed 6 March 2017.

Women for Election (2013), Submission to the Constitutional Convention, Topic VII: Increasing the Participation of Women in Politics, February 2013.

Zemni, Sami (2015), 'The Extraordinary Politics of the Tunisian Revolution: The Process of Constitution Making', Mediterranean Politics 20(1): 1. 